\title{
THE CORRELATION BETWEEN THE CONCEPT "ENGLISHNESS" AND THE IMAGE OF AN ISLAND IN THE LITERARY WORKS OF THE FIRST HALF OF THE XXth CENTURY
}

\author{
Victoria Lozenko \\ $\mathrm{PhD}$, Associate Professor, Kharkiv National Medical University, Ukraine \\ e-mail: arana77@ukr.net,orcid.org/0000-0003-1248-0534
}

\section{Summary}

The concept "Englishness" has been outlined in a large number of literary island works. The image of an island plays the important role in English culture: in architecture we can find crannogs (artificial islands in the middle of a lake), in mythology, history of the English language the research by many specialists has shown that the name of the Isle of Man derives from Manannan, the Celtic god of the sea; in literature a lot of island works are represented. The metaphor "person-island" also figures in the island literary works of the first half of the XX century. In these literary island projections the image of an island reflects the inner world of a person who forgets or, on the contrary, reserves his English identity. The most well-known English island literary works have been examined through the correlation of the image of an island and the concept "Englishness": "The Island Pharisees" by J. Galsworthy, "The Moon and Sixpence" by W. S. Maugham, "To the Lighthouse" by V. Woolf, "Mister Blettsworthy on Rampole Island" by H. G. Wells and "The Simpleton of the Unexpected Isles" by B. Shaw.

Keywords: ethnocultural component, the inner world of the English, isle literature, privacy, personification, interpretation.

\section{DOI: https://doi.org/10.23856/3807}

\section{Introduction}

The image of an island is known to have played an important role in works of world literature, especially English one. In the literary projections the image of an island figures as the key component, which is explained by national mentality of the English. In English island literary works there is demonstrated the concept "Englishness" which conveys the idea of confined place, angle, island, aspiration to privacy.

The aim of the article is to study literary interpretations of the concept "Englishness" in the island works of the first half of the XX century. The research is based on the most wellknown island works of this period: "The Island Pharisees" (1904) by J. Galsworthy, "The Moon and Sixpence" (1919) by W. S. Maugham, "To the Lighthouse" (1927) by V. Woolf, "Mister Blettsworthy on Rampole Island" (1928) by H. G. Wells and "The Simpleton of the Unexpected Isles" (1934) by B. Shaw.

Topicality is determined by a large number of English literary works, focusing of literary studies on the problem of ethnocultural mentality and its role in development of literary process.

Scientific novelty implies correlation of the concept "Englishness" with the image of an island. This research is the first attempt to examine the concept "Englishness" in the island literary works of the first half of the XX century.

Methods of research. The island literary works by G. Galsworthy, J. Conrad, W. S. Maugham, V. Woolf and H. G. Wells are studied by means of polycritical approach which includes cultural, psychological and concept methods. Cultural method contributes to examine 
influence of the epoch and culture on island literary works by writers. Psychological method assesses the link between psychological processes as an author as a reader and poetics of a literary work. Concept method outlines the specificity of the concept "Englishness" in island literary projections.

\section{Approaches to the concept "Englishness"}

The concept "Englishness", its correlation with the concept "Britishness", whether they are synonyms or not at all: these questions are a matter of discussion not only in England but in all countries among people involved in study of English literature or culture. After analysis of scientific works, political discussion, literary works one can draw a conclusion that there can be outlined two approaches: identification of "Englishness" and "Britishness" and negation of similarity between these phenomena.

According to representatives of the first approach (K. Robbins, 1995; N. I. Kostina and D. M. Kostina, 2014) "Englishness" and "Britishness" can be described as an essential component of British culture including territorial, economical and political affiliation, common history, culture, customs $\backslash$ traditions, traits of a character: "Traditionally, British national identity was intrinsically linked with the supposed superiority of Britain's political institutions and the spread of the British Empire. By forging the British nation in opposition to others and otherness, it was possible to unite the disparate classes and nations of Britain around the cultural of its dominant nation, England. This of course reflected the fact that it was the English who had the highest stake in the venture. To have celebrated their own English identity, as the creators and directors of Great Britain, would have been impolite in the extreme" (K. Robbins, 1995: 249-250).

The representatives of the second approach to concepts "Britishness" and "Englishness" (J. Denham, P. Kingsnorth) consider them as different concepts. J. Denham, professor at the University of Winchester, giving the characterization of "Britishness" and "Englishness", thinks that one of the differences between English and British identifiers is their openness to non-English identities. (J. Denham, 10).

P. Kingsnorth, an English writer and thinker, finds out Englishness as the most appropriate word for definition of English identity without racial motives: "This who would seek to divide us along racial or ethnic lines need to firmly and loudly resisted" (P. Kingsnorth, 12).

If Englishness is nationalism in a positive sense of this word without racial or ethnic concepts, Britishness is chauvinism with the idea of national superiority.

All the above mentioned leads to the conclusion that Englishness implies typical features $\backslash$ particularities of England, its culture, some traits of an English character, the worldview of the English, their value guidelines in the point of the English and in viewpoint of others (non-the English).

It is worth focusing on the fact that not any English island literary work is surely to connect with the concept "Englishness". For example, J. Conrad and his literary island novels "An Outcast of the Islands", "Freya of the Seven Isles", "Victory" with the main character, Heyst, by nickname "a captive of the islands". In spite of the fact that the image of an island sets a considerable function in island literary works by J. Conrad, the concept "Englishness" does not have a matter of importance in his works. It can be given various explanations to this fact but there are two unquestionable things: J. Conrad was not an Englishman by national origin and he was not brought up in spirit of English culture from his childhood. He learnt the English language and literature, he admired English culture. However there was no any noticeable scenes in his works where English identity would have outlined. 
One more important thing is that there are a few characters by J. Conrad who are the English (Jasper from "Freya of the Seven Isles"). Conrad's characters are mainly representatives of various nationalities: Willems is a Dutchman ("An Outcast of the Islands"), Heyst is a Swede ("Victory"), Freya and her father are Danes ("Freya of the Seven Isles"), Ricardo and Jones are Latin Americans.

\section{Representation of the concept "Englishness" in the novel "The Island Pharisees" by J. Galsworthy}

J. Galsworthy demonstrates the phenomenon of aspiration of the English to privacy, conservatism, "closeness" to others (non-the English and representatives of lower classes): "Everything seemed divided into classes, carefully docketed and valued. For instance, a Briton was of more value than a man, and wives than women" (J. Galsworthy, "The Island Pharisees", 2007: 229). Snobbery in social, political and even in private life, negation of possibility of having the own viewpoint causes irritation of Shelton, the main character from "The island Pharisees". To belong to higher English class means to have the same opinions, tastes, judgments. Final breaking the link between higher class and Shelton occurs when higher society demands the same "closeness" to non-the English and lower class from the main character. In addition representatives of jet set dictate as an obligatory condition not to have a private $\backslash$ personal judgment, especially moral one: "To show sign of private moral judgment was to have lost your soul and, worse, to be a bit of an outsider" (J. Galsworthy, "The Island Pharisees", 2007: 228). To break this sacral rule (not to have own opinion) means to leave a manour-house Holm Oaks, personification of higher society.

It is worth focusing on the fact that Shelton formulates his private judgment to the contrary conservative viewpoints of the Dennant family and traditional English viewpoint of a gentleman. According to Shelton, a gentleman is a man of being able to sympathize, not a person of noble origin with aristocratic manners.

One should outline a common feature in the Dennant family and Shelton's viewpoint of a gentleman. This common feature is considered to be an English national one. In addition this feature has been studied by G. Gatchev, a Russian philosopher. G. Gatchev has examined English mentality. He emphasizes that a gentleman in English culture is not only a noble person but personality, so called a self-made man (a term by G. Gatchev). In English mentality a gentleman is a person-island with tendency to remote life in his house considered as his own universe, microcosm. By means of such viewpoint of a gentleman the widespread credo "my home is my castle" is represented. This credo outlines aspiration of the English to keep their conservative values (the Dennant family) or, on the contrary, to create other, even different ones becoming a person-island, a self-made man who not only denies everything but proposes a certain positive programme due to which he depends on himself not on other people (Shelton).

\section{The specificity of the concept "Englishness" in the novel "The Moon and Sixpence" by W. S. Maugham}

This island literary work represents two modifications of the island image. Due to interaction of different cultures, mentalities, topical problems are raised: the problem of personal freedom, the question of "openness" and "closeness" of cultures. The image of an island outlines not only a problem of a creative person freedom, but the problem of intercultural interaction. 
The problem of interaction of two cultures exists as a result of social, psychological, communicative guidelines, different viewpoints of morality and behavior of a person. In the novel "The Moon and Sixpence" the problem of communication of European and Polynesian cultures does not depend on their different particularities. However communicative process can be productive when one participant of communication does not require from another one to share, to have the same its traditions, principles of morality, customs; there is no obligatory condition for any culture to confess that some culture has superiority over others. The representatives of Polynesian culture (Tiare, Ata, Dr. Coutras and his wife) are ready for communicative process. The Polynesian are friendly to Strickland and his weird manners. Inhabitants of the tropical island are open-minded people because they belong to different cultures: "Here, on this remote island, he seemed to have aroused none of the detestation with which he was regarded at home $<\ldots>$ To these people, native and European, he was a queer fish, and they took him for granted; the world was full of odd persons, who did odd things; and perhaps they knew that a man is not what he wants to be, but what he must be. In England and France he was the square peg in the round hole, but here the holes were any sort of shape; and no sort of peg was quite amiss" (W. S. Maugham, "The Moon and Sixpence”, 2008: 278).

The image of insular England is characterized by its closeness. It is not Englishness but Britishness in the proper sense of a word. The English are represented as conservative people who take everybody non-common, even a man of genius for a suspect person, their works of art for suspect things. Mrs. Strickland and her children, the representatives of British culture, demonstrate a sort of national superiority when it comes to Tahiti and its inhabitants. Captain Nichols is one more character who admires England, feels as a representative of the nation which is better than other ones: "He frequently declared that England was the finest country in the world, sir, and he felt a lively superiority over Americans, Colonials, Dagos, Dutchmen, and Kanakas” (W. S. Maugham, “The Moon and Sixpence”, 2008: 230).

\section{The literary projection of the concept "Englishness" in the novel "To the Lighthouse" by V. Woolf}

One of the famous literary island works by V. Woolf is "To the Lighthouse" in which two islands are represented: the Isle of Skye and the Hebrides. The Hebrides, this island personifies previous life (before travelling to the Isle of Skye) and "old" relationship between Mr. Ramsay and his children based on hatred and fear. At the beginning of the voyage the main aim of Cam and James towards their father was "to fight tyranny to the death". However at the end of travelling such attitude changes. Children could see not a despot with unquestioning orders but their father, a simple, a common responsible person who wants to protect them: " $<\ldots>$ he was shabby, and simple, eating bread and cheese, and yet he was leading them on a great expedition where, for all she knew, they would be drowned" ( $V$. Woolf, 9). The Hebrides which Cam is watching during the travelling disappears gradually like her negative attitude to Mr. Ramsay. The Isle of Skye with the lighthouse symbolizes new relationship between the Ramsay family based on love, comprehension, tenderness.

The concept "Englishness" is outlined not due to declarations about "great England" (Nichols from "The Moon and Sixpence" by W. S. Maugham, Blettsworthy from "Mister Blettsworthy on Rampole Island' by H. G. Wells, Iddy from "The Simpleton of Unexpected Isles" by B. Shaw). The stream of consciousness used by V. Woolf in her novels shows that a person thinks as an Englishman on conscious and unconscious levels. Throughout the novel, 
regardless how long an action lasts characters recite poetry or prose by English poets, novelists or playwrights: W. Cowper, A. Tennyson, W. Scott, W. Shakespeare, lines from English fairy tales. During the travelling to the lighthouse Mr. Ramsay and his children in the spirit recite most often poetry by W. Cowper.

Mr. Ramsay's children were given nicknames after English kings and queens: " $<\ldots>$ the six children whom used to call after the kings and queens of England - the Red, the Fair, the Wicked, the Ruthless..." (V. Woolf, 9). One of the Ramsay's family guest by name William Bankes also calls their children in the same manner: "He called them privately after the kings and queens of England: Cam the Wicked, James the Ruthless, Andrew the Just, Prue the Fair for Prue would have beauty $<\ldots>$ and Andrew brains" ( $V$. Woolf, 9).

Before travelling to the lighthouse Mr. Ramsay and his children had hardly not quarreled. The reason was Mr. Ramsay's order to go to the lighthouse. This scene reminded Lily Briscoe of an English tragedy: "And it struck her, this was tragedy - not palls, dust, and the shroud; but children coerced, their spirits subdued" ( $V$. Woolf, 9). And then about Mr. Ramsay: "He looked like a king in exile" ( $V$. Woolf, 9).

The stream of consciousness technique, which represents not only the backbone of thoughts and perceptions of characters but the mixture of citations of poetry by English poets, is the means of outlining the importance of the concept "Englishness", the considerable significance to think and to feel as an Englishman.

\section{The correlation between the concept "Englishness" and the image of an island in the "Mister Blettsworthy on Rampole Island" by H. G. Wells}

In the context "person-island" H. G. Wells raises the problem of freedom in the novel "Mister Blettsworthy on Rampole Island". Mister Blettsworthy is raving and thinking that he is a victim of a shipwreck. He was captured by savages after his surviving. He was not eaten by savages due to being considered as an insane man. First a character feels a hostile attitude but then he was claimed as a sacred person due to his delirium. All insane people have been confessed as sacred people a long time ago. A. van Gennep, a French ethnographer, the author of the work "The Rites of Passage", outlines that attitude of savages to strangers can be quite different: from hate and murder of a stranger to confession of a stranger as a sacred creature with magic power (A. van Gennep, 1999: 29-30) like in case of Blettsworthy. The main character got a new status: the Sacred Lunatic. Blettsworthy is honored by savages as an insane dreamer who speaks on the behalf of the Great goddess.

On Rampole island savages have a lot of taboo, tribe bans, prohibitions. Mister Blettsworthy finds out that there are a large number of classifications, metaphors, symbolic words used instead of real names of things or people: "The real name of everyone was consealed. You used honorifics and spoke it the third person. It was forbidden even to use the names of many things" (H. G. Wells, 11). Rampole island savages are cannibals, they eat tribesmen who made ritual misdemeanours: for example, one confused complicated rites. However it was forbidden to say "human flesh". There was used the metaphor "the Gift of the Friend". And instead of "murder" or "punishment by a blow on the head", when it comes to homicide of a tribesman, there can be found the metaphor "Reproof".

Blettsworthy's the most important winning is freedom. It means that the character has the right to give expression to his feelings, to formulate his opinion and thoughts according to his willingness, not due to tough and complicated ritual classification. Mister Blettsworthy's thoughts are considered delirium by savages. It saves his life. 
However, Blettsworthy's freedom has a dialectical sort. On the one hand, nothing stops Blettsworthy breaking primitive laws by islanders. On the other hand, this freedom leads to inner isolation. Blettsworthy suffers from loneliness on Rampole island. It is impossible to find something in common with wild cruel savages. Blettsworthy's inhabitation on Rampole island ends when he faints in the dark cave and recovers himself in New-York. Blettsworthy gets to know that he was raving about five years. The description of Blettsworthy's life after recovering himself takes only few pages to demonstrate the ability of overcoming inner fear, especially fear of formulating opinion of his own. H. G. Wells outlines Blettsworthy's aspiration to coming back to Rampole island. The character participates in World War I and loses his leg. After passing the horrors of war Blettsworthy is convinced that a civilized world is not quite different from primitive Rampole island: "And I realized more than ever I had done, that Rampole island had indeed spread out and swallowed all the world. I hadn't a word to say for civilization in the face of that self-satisfied flow of homicidal knowingness" (H. G. Wells, 11).

At the same time, in spite of disappointment, Blettsworthy confesses achievements of English culture. As an example, he gives a positive sketch of Victorian liberalism. On Rampole island the main character has possibility of taking a look at his culture from a side, to be a "stranger" to compare English culture with Rampole one. Blettsworthy idealizes social and political institutions of England consciously when he is praising his country in the dialogue with islanders: "I gave a sketch of democratic institutions and of the services rendered by the press. I contrasted our kindly constitutional monarchy with the superstitious cultivation of a breed of inferior animals, and our popular church, comprehensive enough to embrace almost every type of belief, with the bloodstained ritualism of the goddess. My vision of Oxford became like a picture of Athens painted by a Victorian artist" (H. G. Wells, 11). Blettsworthy knows very well disadvantages of his country in political and cultural life. But England is his country therefore political life and culture of England are the best for Blettsworthy. Inhabitation on Rampole island is also the way of testing English identity, "Englishness" of Blettsworthy whether he is able to feel and to think as an Englishman in the scope of different culture.

\section{Peculiarities of the concept "Englishness" in the island work "The Simpleton of Unexpected Isles" by B. Shaw}

In the play "The Simpleton of Unexpected Isles" by B. Shaw the concept "Englishness" is represented in the context of a problem of civilization. The metaphor "unexpected isles" is used for definition of any civilization. The British Empire is also "unexpected isles" where a great chaos rules on the territories which had been considered as absolutely stable in economical and political sphere. The image of an island outlines a vain life of many Englishmen. Characters by B. Shaw are perfect physically. However the author avoids giving individual features to characters except Pra and Prola (founders of a new civilization), Iddy. Hyering and Sir Farwaters with their wives are described as aesthetes interested in enjoying life and perfect physical appearance. Maya, Vashti. Janga and Kanchin are demonstrated as abstract beautiful idols guided by illogical instincts in life, they have never been taught to think, they have no moral principles, feeling of conscience or mercy: "Kanchin. Let us die for something!" or "Maya. We have no minds. IVashti. We have imagination" (B. Shaw, 8).

In this play B. Shaw denies the possibility of creating in future beautiful but narrow-minded civilization in archaic origins when a person has not learnt to think and evaluate his actions. Such trials lead to anticivilization, a primitive community in which illogical instincts 
will be only taken into consideration. The positive idea of a man of future is represented in Iddy, the only character who realizes his English identity. According to simpleton Iddy (the diminutive for "idiot"), all trials to create a new civilization without realizing oneself the Englishman will fail. All characters are laughing and mocking at Iddy, offending and even beating him.

However at the same time B. Shaw emphasizes that Iddy is the personification of life wisdom, common principles of morality. The wide lawn in a front of a stately house where Iddy enjoys teaching other characters symbolizes deepness of his thought. Englishness is only characteristic feature of Iddy who misses England and everything associated with his country: "England that is me: I that am England! Damn and blast all these tropical paradises: I am an English clergyman; and my place is in England! Floreat Etona! Back to England and all that England means to an Englishman!" (B. Shaw, 8).

The image of a tropical island is defined as "unexpected", i.e. step by step a reader finds out new characteristics of an island which are not expected to see: at the beginning of the play the island is the symbol of death (officials committed to suicide), then the island personifies development of a new civilization, and, at last, its decline. The image of the island is connected with the concept "Englishness": there is no any possibility of creating something new, beautiful and stable if one forgets or denies his identity (English in the play).

\section{Conclusions}

The tendency uniting the studied island literary works is in the fact that the island image gradually loses the features of a real place and it is perceived by characters as fantasy, illusion, dream, even delirium (B. Shaw, H. G. Wells, V. Woolf). Such a perception is typical for the first half of the XXth century when a person tried to escape from reality to the world of fantasy in order to create a new reality (the imaginary Rampole island, the Unexpected Isles).

The image of an island in the studied English literary works is personification of the specific inner world of an Englishman, which is represented in the aspiration to isolation, privacy, the widespread credo "my home is my castle". Even when the remote island is left, characters keep feeling lonely, undergoing spiritual isolation leading to depression. The island is the symbolic image of a complex inner process demonstrating an attempt of a person to realize himself.

The concept "Englishness" has different interpretations in the studied English literary works. The image of an island created by J. Galsworthy and W. S. Maugham exposes island snobbery of the English and their tendency to conservatism: in the "The Island Pharisees" by J. Galsworthy Holm Oaks is metaphorical personification of snobbery of the English. The name "The Island Pharisees" by J. Galsworthy describes not only geographical position of the country but also narrow-minded civilized England with its "island" prejudice. The island in the novel by J. Galsworthy reflects confined views of the English. In the novel "The Moon and Sixpence" by W. S. Maugham opposition of two islands: Tahiti, tolerant to all nationalities, and England with contempt to non-English.

The description of an island as an illusion when a person can not escape from loneliness (H. G. Wells) or an island as a place for setting a problem of island snobbery (B. Shaw, W. S. Maugham, J. Galsworthy) is the specific feature of the image of an island in the first half of the XX century. The image of an island correlates closely with the concept "Englishness" because an island is considered as the place of testing English identity (B. Shaw, H. G. Wells, V. Woolf) or working out interpretation of the concept "Englishness" of his own (J. Galsworthy). 


\section{References}

Conrad, J. Freya of the seven isles. URL: http://www.online-literature.com/conrad/3131/ Galsworthy, J. (2007). The island pharisees. Saint-Petersburg: KARO.

Gatchev, G. (2008). Mentalnosti narodov mira [Mentalities of peoples of the world]. Moscow: Algoritm. [in Russian].

Gennep van, A. (1999). Obryady perehoda [The Rites of Passage]. Moscow: Vostochnaya literatura. [in Russian].

Kostina, N. I., Kostina, D. I. (2014). Yazykovaya spetsifika vyrazheniya kontseptov "Englishness" $i$ "Britishness" $v$ sovremennom britanskom mediadiskurse [Peculiarity of expressing the concepts "Englishness" and "Britishness" in the modern British medias discourse]. Belgorod: Nauchnye vedomosti. [in Russian].

Maugham, W. S. (2008). Rain. Stories. Saint-Petersburg: KARO.

Robbins, K. (1995). An imperial and multinational polity. Uniting the kingdom? The making of British history.

Shaw, B. The Simpleton of the Unexpected Isles. URL: http://gutenberg.net.au/ebooks03/ 0300481h.html

Woolf, V. URL: http://gutenberg.net.au/ebooks01/0100101.txt

URL: https://blogs.lse.ac.uk/politicsandpolicy/is-it-the-english-or-the-british-question/

URL: http://freeread.com.au/@RGLibrary/HGWells/Novels/MrBlettsworthyOnRampoleIsland.html

URL: https://www.opendemocracy.net/en/response-to-a-jigsaw-state-breaking-up-britain/ 